\title{
Recognition in Programmes for Children with Special Needs
}

MARJETA ŠMID ${ }^{1}$

$\approx$ The purpose of this article is to examine the factors that affect the inclusion of pupils in programmes for children with special needs from the perspective of the theory of recognition. The concept of recognition, which includes three aspects of social justice (economic, cultural and political), argues that the institutional arrangements that prevent 'parity of participation' in the school social life of the children with special needs are affected not only by economic distribution but also by the patterns of cultural values. A review of the literature shows that the arrangements of education of children with special needs are influenced primarily by the patterns of cultural values of capability and inferiority, as well as stereotypical images of children with special needs. Due to the significant emphasis on learning skills for academic knowledge and grades, less attention is dedicated to factors of recognition and representational character, making it impossible to improve some meaningful elements of inclusion. Any participation of pupils in activities, the voices of the children, visibility of the children due to achievements and the problems of arbitrariness in determining boundaries between programmes are some such elements. Moreover, aided by theories, the actions that could contribute to better inclusion are reviewed. An effective approach to changes would be the creation of transformative conditions for the recognition and balancing of redistribution, recognition, and representation.

Keywords: recognition, patterns of cultural values, children with special needs, inclusion

1 Primary school Jela Janežiča, Slovenia; marjeta.smid@guest.arnes.si. 


\section{Pripoznanje v programih za otroke s posebnimi potrebami}

MARJETA ŠMID

$\propto$ Namen prispevka je analizirati dejavnike, ki vplivajo na vključevanje učencev (inkluzijo) v programih za otroke s posebnimi potrebami s perspektive teorije pripoznanja. Koncept pripoznanja, ki vključuje tri vidike socialne pravičnosti - ekonomskega, kulturnega in političnega -, zagovarja, da na institucionalne ureditve, ki učencem s posebnimi potrebami ne omogočajo partnerskega sodelovanja v življenju vrstnikov v šoli, ne vpliva samo distribucija, ampak nanje vplivajo tudi kulturni vzorci vrednot. Študij literature je pokazal, da na ureditve šolanja otrok s posebnimi potrebami vplivajo zlasti vzorci kulturnih vrednot (ne) zmožnosti in manjvrednosti ter stereotipne predstave o učencih s posebnimi potrebami. Zaradi velikega poudarjanja učnih sposobnosti za akademsko znanje in ocene se manj posveča dejavnikom rekognicijskega in reprezentacijskega značaja, kar onemogoča izboljšanje nekaterih pomembnih elementov inkluzije. Vsakovrstna participacija učencev $\mathrm{v}$ dejavnostih, vidnost učencev zaradi dosežkov, slišanost učenca in problem arbitrarnosti pri določanju meja med programi so nekateri med njimi. Ukrepi, ki lahko pripomorejo k boljšemu vključevanju otrok s posebnimi potrebami v šolo, so analizirani s teoretičnega vidika. Učinkovit pristop k spremembam bi bil oblikovanje transformacijskih pogojev za pripoznanje in uravnoteženje redistribucije, rekognicije in reprezentacije.

Ključne besede: pripoznanje, kulturni vzorci vrednot, otroci s posebnimi potrebami, inkluzija 


\section{Introduction}

Slovenia is included in European and global processes of inclusion. The formal framework for the inclusion of children with special educational needs (hereinafter referred to as children with SEN) in primary school was given with the Placement of Children with Special Needs Act / ZUOPP / (2000) (hereinafter referred to as the Placement Act). The current Placement of Children with Special Needs Act / ZUOPP-1 / $(2011,2012)$ and the Rules on the organisation and work methods of commissions for the placement of children with special needs (2013) (hereinafter referred to as the Rules on the work of commissions) provide as a rule, for children with minor mental disabilities, an education in an adapted basic school programme with lower educational standards (hereinafter referred to as LES) (Rules on the work of commissions, 2013, Article 9), and for children with moderate, severe and profound mental disabilities an education in a special programme (hereinafter referred to as SP) (ibid., Article 10). The most diverse and the largest is a group of pupils who receive educational programmes with adapted implementation and additional professional assistance (hereinafter referred to as APA) (ibid., Article 7). The APA programme is implemented in regular classes (the Placement Act, 2011, Article 18, paragraph 2). The adapted LES programme is implemented in primary schools in regular classes and classes with adapted programmes and in schools that are established and organised for the implementation of these programmes, as well as in institutes for the education of children with SEN. The SP is implemented in schools and extra classes near schools that are established and organised for the implementation of adapted educational programmes and SP education, institutions for the education of children with SEN and social care institutions (ibid., Article 18, Item 4).

Hočevar (2010) shows the indicators of inclusion in Slovenia, which must be take into consideration, are the methods of evaluation and promotion (standards of knowledge), financing methods, school culture and climate (the need to introduce counselling for teachers, pupils/children with SEN, peers, parents, environment), legislation that regulates the field of special needs (difficulties in implementing the Act) and teacher training (the need for training about children with SEN in all profiles of future teachers). In the analysis of the education of children with special needs in Slovenia, Opara et al. (2010) highlighted the problem of the network of institutions for the education of children with special needs, the lack of adequate staff, especially the special teachers and rehabilitation teachers for different types of deficiencies. In primary schools with adapted programmes, the importance of their transformation into professional and support centres was emphasised. Fields to which attention must be 
paid are the help for children with SEN in the preschool period, the integration of different disciplines and the overhaul of lower vocational education, which is decreasing in importance (Opara et al., 2010). The same authors (ibid.) identify the lack of authority which would provide and coordinate the process of the education of persons with special needs. They propose a new definition of placement procedure, the elimination of ambiguities and shortcomings of the legal bases and documentation, and further projects on simultaneous implementation of the adapted programme with a lower educational standard and an equal educational standard (Opara et al., 2010).

Furthermore, the provision of the legislation that allows transitioning between programmes (Placement Act, 2011, Article 17) is not carried out in practice. In the framework of the 'Stimulating Learning Environment for Ensuring Equal Opportunities in Education' project, the National Education Institute Slovenia (NEIS, 2015) has prepared a questionnaire for the involved primary schools with an adapted programme on the transition of children with SEN from the LES programme to the regular educational programmes. The project and its questionnaire have not been offered to regular primary schools; the information on the transition was thus one-sided. According to De Silva (2013, p. 419), who refers to Meijer, the 'behaviour and social and/or emotional problems, combined with dealing with differences or diversity in the classroom are the most challenging in the area of pupils' inclusion in European classrooms.' With this De Silva indicates an extremely problematised area of inclusion, i.e. the existence of poor interpersonal relationships between different pupils and the need to improve them. This is confirmed in practice, and the research has also often expressed the need for additional attention in shaping interpersonal relationships among peers (Brenčič, 2011; Estell et al., 2008; Kellner, Houghton \& Douglas, 2003; Prah, 2011; Webster \& Carter, 2013). The other highly problematised area in the inclusion is the knowledge assessment of children with SEN. In the research, the authors describe a fairly successful inclusion of the various groups of children with SEN, also in the learning area (Meadan \& Monda-Amaya, 2008; Novljan, 2005; O'Rourke \& Houghton, 2006; Schmidt \& Čagran, 2005). Learning outcomes are not high, but sufficient for the pupils to show progress. Nevertheless, Končar and Lakič (2004) have established the presence of fear and anxiety of school in pupils who attend the LES programme, precisely because of the low educational achievement. Expert analysis of the results of the Slovenian national assessment of knowledge in the APA programme has consistently showed over the years the low achievement of children with SEN, compared to their peers without special needs (Košir, 2008; RIC, 2014), which may be because of programmes that are too difficult and the inadequate 
functioning of the support structures of schools. The low results of children with SEN in national assessment indicate inconsistency with the findings of the research that indicate good achievements of children with SEN. Difficulties in the assessment and manner of implementing work with the children with SEN in the class are significant. The authors Anastasiou and Kauffman (2011, p. 380) and McOuat (2011, p. 125) warn that a pupil with SEN in the class is not the same as the other twenty-five, who also require the teacher's time. The individualisation in classes is hardly realised, if we believe that in inclusion all pupils should, even by force, make progress according to the same criteria. Individualisation is also often wrongly equated with working with individuals (Rutar, 2011a, p. 174), when it mostly means taking into account everything that individuals bring into the learning situation (Rutar, 2011b, p. 53).

The research of the effectiveness of the inclusion remedies, and even determining whether a certain intervention can be described as inclusive at all, are also and in particular affected by the participants in each study (Lindsay, 2007). In studies, the most involved are children with learning difficulties, specific learning difficulties (from mild to severe), the physically disabled, deaf and hard of hearing, blind and visually impaired pupils, children with emotional and behaviour disorders, and children with mild, moderate, and severe intellectual disabilities. Comparisons between them cannot be made directly since in each study we need to determine exactly which pupils were involved. Moreover, the authors of the research have established an extraordinary diversity in defining individual areas of inclusion, in the terminology used, methods, approaches, and types of research, and consequently diversity in the results and findings (Koster, Nakken, Pijl \& van Houten, 2009). For example, in the field of interpersonal relationships, authors (Koster et al., 2009) have explored the concepts of social participation, social integration, and social inclusion. They reviewed sixty-two research articles and found that there is an overlap in the use of these three concepts because they are used as synonyms. The research of inclusion is also aggravated due to the absence of a strong concept or theory of inclusion (Armstrong D., Armstrong A. \& Spandagou, 2011; Juriševič, 2011; Winkler, 2011). The 'formidable set of factors' may represent a difficulty in implementing inclusion' (Lindsay, 2007, p. 5) and a range of indicators, which are to be taken into account for effective practice and research, however, at the micro level; the teaching staff with their abundance of work might be discouraged in implementation of these factors. Teachers often do not know how to bring inclusion into classrooms. De Silva (2013, p. 431) states the dilemma of teachers that 'the university is talking about inclusion, but the question is what is really good for the child, whether to teach her in an excluded environment or 
put her into an environment where she is time after time rejected by her peers.' De Boer, Pijl, and Minnaert (2011) stated that teachers must be trained to work with children with SEN, and should at least attempt to accept inclusion as a part of their value system and not only as a content or method, because they have the greatest impact on the success of inclusion in the classroom.

The theory that highlights the inclusion of particularly vulnerable groups in society more comprehensively, and that can better cope with the problems of the inclusion of children with SEN in school practice, is the theory of recognition (Artiles, Harris-Murri \& Rostenberg, 2006; Bingham, 2006; Fraser, 1997, 2000, 2003, 2003a; Higgnis, MacArthur \& Kelly, 2009; Keddie, 2012; Kroflič, 2010a, 2010b; Rutar, 2011a). In addition to the equitable distribution of goods, for the best performance of the individual (redistribution, also known as the economic dimension), it puts the importance of proper recognition in the spotlight, where a person is viewed in a positive light because of the achievements and recognition in interpersonal relations (recognition or cultural dimension), and the importance of the environment in which the various participants are allowed all manner of participation and decision-making (representation, also called the political dimension). The critical theory of recognition placed the distribution requirements at the centre of ensuring social justice (Fraser, 1997, 2000, 2003, 2003a; Honneth, 2003a; Keddie, 2012). The essential difference between the redistributive dimension, within the meaning of recognition theory, and pure forms of distribution in the conventional sense, is the highlighting of distribution, which extends over the entire range of social relations, including those which are usually 'treated as cultural' (Fraser, 2003a, p. 86; Honneth, 2003a). There is an inadequate distribution due to inadequate economic structures of society, and the recognition reflection discovers inadequate distribution as a result of institutionalised forms of society because of the existing cultural values, which is one of the essential contributions of recognition theory. The finding that not only economic injustice exists, but also that cultural injustice is equally unfavourable, is the reason for the formation of the theory. Recognition requires such an interpretation, presentation, and communication, which enables a group or an individual to achieve parity of participation $^{2}$ with peers in social life (Fraser, 2000, p. 115). Parity of participation necessarily involves transforming oneself, which is an essential element of recognition (Fraser 2003a; Galeotti, 2009). Regarding educational institutions (kindergarten, school), the transformation that creates conditions for changing

2 Fraser's expression 'parity' means 'the conditions of being a peer, of being on a par with others, of standing on an equal footing' in a given activity or interaction (Fraser, 2003a, p. 101, note 39; 2000, p. 113). 
oneself and own values was identified by the authors Bingham (2006) with critical thinking about oneself and the wider social context, Higgins et al. (2009) with transformative diversity, Rinaldi (2006) with the concept of visibility, and Artiles, Kozleski, Dorn and Christensen (2006) with the transformation of identity. Cultural injustice is connecting the theory of recognition with complex problems of inclusion. We have found that there is research that addresses the views of teachers (e.g. Čagran \& Schmidt, 2011; De Boer, Pijl \& Minnaert, 2011); however, there are still no papers that attempt to tackle the problem of inadequate patterns of cultural values in relation to inferiority.

First, the question arises of what exactly those cultural values of the society that are the basis for institutionalised arrangements in such a way that some of its members or groups have no possibility for cooperation with their peers in social life are. It is important to understand what the institutionalised society forms represent in the light of theory. They represent any form of social arrangement, in particular, legislation, policies and public institutions in which citizens can exercise their rights (Fraser, 2000, p. 115). The institutionalised forms that are highlighted in this article are the APA, SP, and LES programmes. The sought patterns of cultural values that affect the recognition of an individual or a group are derived from social and cultural patterns of representation, interpretation, and communication:

Examples include cultural domination (being subjected to patterns of interpretation and communication that are associated with another culture and are alien and/or hostile to one's own); non-recognition (being rendered invisible via the authoritative representational, communicative, and interpretative practices of one's culture); and disrespect (being routinely maligned or disparaged in stereotypic public cultural representations and/or in everyday life interactions) (Fraser, 1997, p. 14; also Fraser, 2003a, p. 13).

Inappropriate patterns of cultural values affect the status of the group, which is set at a disadvantage and which is consequently prevented or impeded from participating in social life.

In practice, we often witness arrangements of the schooling and treatment of children with special needs in which they are prevented from full participation in the life of class and school, and they are not sufficiently academically successful, are not accepted and cannot make decisions; we have established that these arrangements are influenced by patterns of cultural values, including in Slovenia. We cannot implement good inclusion without considering the latter; the following questions arise: which cultural patterns of values hinder the participation of children with special needs and how; what dangers for inclusion can be identified through the concept of recognition from the 
economic, cultural, and political points of view, and what remedies can improve these practices of inclusion/participation of children with special needs?

With the help of literature, taking into consideration the concept of recognition through the analysis of redistribution, recognition, and representation, the paper will first show how to discover the arrangements that are affected patterns by cultural values, what are the dangers in inclusion, and below, which remedies can prevent them.

\section{Effects of patterns of cultural values}

In the field of education of children with SEN, inferiority is a powerful cultural prejudice. The 'marginalised knowledge' stands behind this idea (Danermark \& Coniavitis Gellerstedt, 2004; Keddie, 2012, p. 272). Behind the idea of the inferiority of children with SEN is a hidden idea of the superiority of the majority population (Keddie, 2012).

Preconceived notions of inferiority can be seen in the incorrect placement of the children with SEN in programmes. In Slovenia, insistence on the placement in too demanding programmes is present to a greater extent (Krek \& Metljak, 2011; Rovšek, 2009, 2013). LES or SP programmes are avoided above all, and children are being placed in other groups of children (Rovšek, 2013). Parents do not want their children to be classified as children with SEN, particularly not as children with minor or moderate mental disabilities, and do not want placement in separate schools, which are also under the influence of inadequate patterns of cultural values. Parents have no say in choosing the school, because the location of the programme implementation is established by a decision of the commission for the placement of children with special needs. Universalistic terms, such as 'mental disability' and 'special programme', are probably no longer appropriate since they arouse reluctance; however, the relevant legislation applies them. Galeotti (2009) recommended the constant changing of the universalistic terms until the use of them no longer makes anyone feel affected. Although the placement into the LES or SP programme is reasonable, however, the law and expert opinions have no effect or, as it is critically stated by Rovšek (2009, p. 358): 'The system and practice allow enrolment of any child with special needs in almost any programme.' Inadequate patterns of cultural values prevail in both parents, and (it also happens) in teachers.

Examples of incorrect recognition, which leads to feelings of inferiority and is reflected in avoidance of visibility (e.g. avoidance of activities) and subsequently to retention of subordination, was observed by Higgins et al. (2009) and Čačinovič Vogrinčič (2013). Higgins et al. (2009) found that, for example, 
a pupil with speech impairment preferred to be quiet among other healthy pupils, so that her deficiency would not be evident. Another pupil wrote a letter because she did not dare to speak out loud about why she was late for class.

In the area of redistribution, the objective of economic conditions is such a redistribution of goods so that all individuals or groups in society are guaranteed the best resources for development and realisation of their abilities, which allows them to participate in social life (Robeyns, 2009; Solveig Reindal, 2010). In the educational system for children with SEN, identifying their skills is one of the main areas that affect the distribution of resources. Addressing the children with SEN as incapable or capable carries the risk of incorrect or insufficient provision of redistribution resources for the development and implementation of capabilities, and prevents their participation (Kroflič, 2010a). One of the consequences of such a view of children with SEN is the insistence on the traditional way of teaching, which puts the teacher in the role of an active mediator of knowledge, and the pupil in the role of passive receiver, simply because in the traditional view of teaching a child is not yet mature and is not able and competent to learn in an active way (Koren, MacBeath \& Lepičnik-Vodopivec, 2011). Active learning in contrast to traditional learning is based on social learning, which is absolutely associated with communication, social networks, and relationships (ibid.). In doing so, the impaired children are doubly disadvantaged. Firstly, because they are children, and secondly, because they are impaired children and additionally seen as incompetent, and incapable of equal communication as the rest are. The testimonies of impaired children point to their constantly proving that they are capable of doing something and know how to do it; however, lower grades are reserved for them (Higgins et al., 2009, p. 478-479). They must demonstrate their inabilities in order to obtain certain rights; this is an example of the norms and standards for children with SEN. A significantly reduced number of students is possible in the framework of LES programmes and in SP (Rules on norms, 2007, 2008, 2014), and a significant lowering of educational requirements is possible in the LES programme (Adapted educational programme..., 2003, 2013). In the mainstream primary school programme of an equal educational standard, the right, for example, to the pre-written material, extended time to solve the assignments or to use a tablet computer is related to the educational programme with adjusted implementation and APA. With the latter, the pupil gains the right to receive an individualised programme in which the adjustments are written down. Therefore, the rights to adjustments in the classroom are related to the programme.

Another example of redistribution demonstrating the ability of SEN children is granting the possibility to attend certain options of educational 
programmes. The pupil in the LES programme who achieves equivalent educational standards in a particular subject area shall acquire the right to transition at this subject (Placement Act, 2011, Article 17); however, this is rarely exercised in practice. The reason may be the absence of a continuum of help with the transition, and the operationalisation of the transition is also not determined with regard to regulations or otherwise.

Keddie (2012) and Higgins et al. (2009) believe that the teacher training system also shows some inappropriate patterns of cultural values in the treatment of children with SEN. Some teachers are more oriented, for example, towards the knowledge of mathematics, and others towards specific skills for working with children with SEN. Even teachers believe that they do not need additional knowledge in higher classes (e.g. in mathematics) in order to teach children with SEN, while others believe they need no in-depth knowledge about children with SEN, which reflects their low expectations (Lingard, 2007; Keddie, 2012, p. 270). One of the most important theoreticians of recognition in the field of education, Keddie, believes that high expectations of teachers towards pupils' knowledge are a part of the economic right, i.e. the redistribution that is provided by teachers (2012, p. 270). The problem of economic redistribution can be seen in programmes that have a curriculum that is not accessible to all, because the availability of curriculum is an element of redistribution (Higgins et al., 2009; Keddie, 2012). As a result, an overly demanding programme does not allow pupils to demonstrate their skills sufficiently and prevents them from achieving academic success and positive visibility.

Furthermore, the representation may be under the influence of the dominant patterns of cultural values of inability and inferiority, which puts children with SEN in a subordinate position. Good representation represents all kinds of cooperation of children with SEN in the classroom and in the school community and enables them to make decisions about themselves. The right of children to be provided with opportunities for participation in decision-making in matters relating to themselves, their actions and learning have been part of the Convention on the Rights of the Child since 1989 (Articles 12 and 13). Within the theory of recognition, the 'voice of the child' is determined by the authors Smith (2007, p. 14), Higgins et al. (2009, p. 474), Rutar (2011a), Kroflič (2010a, 2010b) and Bingham (2006). Higgins at al. (ibid.) and Kroflič (ibid.) note the right of a child's voice to be heard as distinct from the majority. There is ample evidence that children with learning disabilities with lower abilities to communicate often experience involuntary communication embargo and the deprivation of the right to express their opinion, the right to participate, and the right to independent decisionmaking about themselves (Higgins et al., 2009). Higgins et al. (ibid.) note that 
these points are particularly critical at the interpersonal level in the classroom, in the lesson and school activities, and in activities outside school. Failure to exercise the articles of the Convention on the Rights of the Child (1989) on the right to the voice hinders children with SEN in inclusion to educational programmes and their right to active participation in the educational process and, therefore, in relevant social contexts. Higgins et al. (2009, p. 476) named the elements of dimensions of representation as 'agency'. The researchers Olli, Vehkakoski and Salantera (2012), who conducted an extensive analysis of the literature on the agency of pupils with SEN, have found that exercising the agency of children with SEN is strongly linked to the previous condition of capability. Regarding a pre-requisite of capability, neither the Convention on the Rights of the Child (1989) nor the Convention on the Rights of Persons with Disabilities (2006) are exceptions. In the first case, the right to express her/his own views is ensured only to a child who is capable of forming those views; in the second case, the right is linked to the age and maturity of the child. In both cases, the conventions are promising many rights to children, but at the same time, they give adults the power to decide who can use those rights (Olli et al., 2012, p. 794).

Analysis of the representational dimension also allows a critical look at the contexts or areas where participation takes place. Initially, the dimension of representation in the part that relates to the framing failed to attract more attention of authors who focus on children with SEN in their papers. Primarily, the main problem was posed by the lack of opportunities to participate in the wider community, as provided by the respective school framework (Higgins et al., 2009; Kogovšek et al., 2009). Honneth (2003b, p. 185) and Kogovšek et al. (2009) have accentuated the importance of extending opportunities to participate and thus the importance of a broader framework of inclusion. The opinion that the impaired children are 'passive, incompetent, sensitive and are all the same' (Kroflič, 2010a, p. 8) may be the reason that schooling is designed in a way that participation is not possible for them at the outset; thereby the spaces of participation are narrowed. We have found that the abilities of children with SEN are a criterion by which the institutional rights are also allocated in the area of representation. For example, skills and academic performance are the criteria by which the right to participation in separate individual programmes is acquired, where the child's voice can be heard much better (Keddie, 2012).

\section{Dangers for recognition are dangers for inclusion}

Discussions of recognition theory currently take place in two directions; the first is based on the identity model of recognition and the other on the 
status model of recognition, on which the above three-dimensional model of the theory is based. Despite the general acceptance of identity policies, which emphasise the reciprocity of recognition for self-development and the right to one's own original identity, from the perspective of the theory, treating the recognition policy as being equal to identity policy presents a problem (Fraser, 2000, 2003a). The identity model treats the incorrect recognition only as a harm in the cultural field. As a result of the excessive emphasising of identity, Fraser (2000, 2003a) has firstly defined two dangers of recognition. The first is the displacement of redistribution needs, i.e. clouding of the origin of redistribution injustices, also the evasion of their connectedness with recognition needs. The second danger is the highlighting of providing the possibility of identity forming as the sole criterion of fair recognition, causing the reification of group identities. Unlike the identity model, the status model does not emphasise a specific group identity, but the status of the individual as a full partner in social interaction. The criterion for assessing the performance of recognition is, therefore, the parity participation or guaranteed participation in advance, in recognition as well as redistribution and representation (Fraser, 2003a, p. 38).

The risk of displacement can also occur when dealing with children with SEN. Thus, a great deal of human and material resources can be invested in better learning achievement, while disregarding the importance of the material resources necessary for successful inclusion into other activities of class or school and relationships, which was also found by Slovenian researchers. Frequently, the objective of lesson adjustments is only to improve the academic aspect of education, while the re/habilitation aspect of the treatment is given insufficient sensitivity (Kogovšek et al., 2009, p. 408). Pretnar (2012, p. 154) believes that exposing only educational indicators as key in determining the success of school is in conflict with the enforcement of inclusivity: 'The latter is bad, if a child with SEN is only included among peers without the environment being prepared for the child and without receiving a proper support'. Rutar (2011a) draws attention to the excessive emphasis on formal organisational remedies, which might mean investing too much effort in the direction that certainly at least the children do not wish for, if we consider that they mostly wish to be accepted, to have the opportunity of participation, to be welcome and appreciated in the group.

In the lowering of standards and in the creation of different criteria in achieving academic achievement within the curriculum, Keddie (2012, p. 270) identifies the problem of displacement of resources, names different 'measuring sticks', and emphasises the need for the 'same measuring sticks' of educational achievement. Different informal standards appear in the same program: one is applied for one group of pupils and the other for the other pupils. Different 
measuring sticks prevent certain pupils from being more successful and therefore prosper better in life. Kavkler, Košak Babuder, and Magajna (2015, p. 46) have also observed a reduction in the difficulty of the tasks: 'In the teaching and testing processes, the school's education professionals often merely reduce the complexity and abstractness of assignments instead of enabling children specific adaptations in reading, writing, arithmetic and spelling (e.g., adjustments in study materials, the use of study and technical aids, longer times, etc.)'. They emphasised the need for better adjustments instead.

Reification (in our case, it can be understood as management with children with SEN) can be interpreted in a way that the lower performance of children with SEN is either due to the cultural background or the inability of the child to do the school work and less a consequence of economic regulation. In the background of such definitions is the tendency of the majority for the specific treatment of children, or possibly the non-treatment of children (Turnšek, 2008). The contribution of children with SEN and questions about children with SEN in schools can be presented with the lack of aesthetic sense. Children with SEN are bereft of 'aesthetics', if culturally inclusive teaching is reduced to representation in which the identity of children is deprived of complexity, which also leads to reification (Keddie, 2012, p. 270). The results of the Slovenian research of authors Ozbič and Žolgar Jerković (2007) have shown general misconceptions of future teachers about children with SEN, oversimplification and generalisation of their personality, and orientation to the disorder as if they are without the need for participation. Inclusion would be much more successful if teachers would know the actual capabilities of children with SEN (in the case of the research of the deaf, hard of hearing) and would not lean on stereotypes and misconceptions (ibid.). Stereotypical and superficial descriptions of children in LES and SP, which incorrectly inform the wider community about their abilities, contribute to stigma both on the interpersonal level as well as at the level of the institution. Reification can be seen at the school level. Highlighting the special needs of pupils brings several advantages to adults, guardians or educators, especially with regards to distribution. Due to such rights (e.g. in school to lower criteria in the classroom or more hours of APA), children with SEN may be held in inappropriate programmes. In reification, the 'desirable' membership or biodeterminism and paternalisation are seen (Keddie, 2012, p. 274) or, for example, the 'ordered' choice (Batistič Zorec, 2010). It is likely due to help from the deployment of teachers in the programmes of APA, LES or SP. Teachers who teach in regular school (APA) have no contact with pupils in the LES or SP and vice versa. Within the programmes, everyone is holding to their work and does not want to accept new work. 
In terms of the identity model, due to non/highlighting the characteristics of an individual or a group in comparison with others (descriptions of differences), the ways of participation may be provided or places where individuals or groups participate may be restricted; therefore, the right in the political field is under threat (Fraser, 2003a; Olson, 2008). Olson (2008) notes that the avoidance of visibility and patterns of cultural values are deepening the disrespect, especially if the boundary between groups is arbitrary. The participation itself is arbitrary, and thus of a political nature (Olson, ibid., p. 252), where the right to participate on the basis of differences is provided to participants by a third party, the non-involved, or the stronger one. In LES, APA and SP programmes, the condition of arbitrariness is fulfilled; namely, the boundary between them is identifiable, and thus the spaces of participation are too, so the pupils and guardians should have a choice regarding participation in them.

\section{Corrective remedies}

Remedies that would aid in understanding and eliminating problems and injustices are divided into the affirmative and the transformative (Anderson, 2008; Christensen, 1996/2004; Fraser, 1997, 2003a; Galeotti, 2009). The aim of affirmative remedies is to correct the inadequate consequences of social arrangement without disturbing the basic social framework that generates injustice or may even cause new ones (Fraser, 1997, 2003a). Remedies aimed at the correction of inappropriate consequences with the reconstruction of the basic generative structural framework are the 'transformative remedies' (Fraser, 1997, p. 23; Fraser, 2003a, p. 74). Affirmative remedies in the APA programme are the adjustments, which are mostly determined in two ways: the first is the determination of adjustments with a decision (Placement Act, 2011, Article 30), and the second with an individualised programme (ibid., Article 36). Adjustments are extremely important but are not sufficient to create the transformative conditions, which means that users can become accustomed and dependent on them in the long run (Galeotti, 2009). Recipients of the remedies are aware that their achievements can be the result of pre-allocated choices without their own contribution, which may lead to stigmatisation and subordination (ibid.). Although with the adjustments, we want to reduce the differences between pupils, we are establishing new ones with them. Therefore, caution is important when evaluating the achievements of children with SEN, so that they are not the result of pre-allocated choices, but are a reflection of actual knowledge.

Kogovšek, Ozbič, and Košir (2009) have found that the inclusion of children/pupils/students is usually reduced solely to the presence of a child with 
minimal adjustments. This represents only declarative inclusion without structural and deep changes to the system, which does not take into account the whole person (in the case of the deaf/hard of hearing), but is changing only some superficial elements of education (Kogovšek et al., ibid., p. 406).

The most commonly adopted affirmative remedies are education (Fraser, 2003a) and coping with diversity (Anderson, 2008). Much was promised for the hour of advisory services (Placement Act, 2011, Article 8, second indent), which is an additional remedy of education of children with SEN, but we still do not know its practical effect, especially since the concept of assessment of advisory services was modified during its application in practice (Kovšca, 2014; Šoln Vrbinc, Jakič Brezočnik, Arnuš Tabakovič, 2014). The remedy of advisory services is otherwise remarkable because, in the original idea (Kovšca, ibid.) and for the first time within Slovenian legislation, the redistribution would not be devoted only to academic knowledge, but also to participatory processes of children with SEN. There is a likelihood that the advisory service exists only on paper, because the additional distribution was not realised. Therefore, the practitioners of educational institutions often see it as unnecessary; it brings them additional administrative work, and it does not contribute to the quality of work with children with special needs. Having additional education of the environment of children with SEN, with operationalisation and creating a continuum of assistance, the transition between programmes might be more easily established. It is important to understand that the 'cultural curriculum', which serves only for information about diversity, represents an affirmative remedy, which symbolises integration more than the essence of inclusion. It is important to say that the correction of affirmative remedies brings the possibility of choice (Fraser, 2003a).

More desirable are the transformative remedies that change the structures that cause problems. An essential element of the transformative remedy is the fact that better regulation is provided in the principle (Fraser, 2003a, p. 77). We may take into consideration the authors Artiles, Bal, and Thorius (2010, p. 250), who have defined the 'transformative curriculum'. Intersubjective conditions are formed with them, by which information is provided about difference, and everyone changes the awareness of oneself (Artiles, Kozleski et al., 2006; Bingham, 2006; Higgins et al., 2009; Rinaldi, 2006). The change of oneself, therefore, one's own attitudes and values, however, happens only voluntarily or spontaneously (Bingham, 2006). Bingham (2006) and Kroflič (2010) have identified concrete transformative techniques for direct work with pupils. According to Bingham (2006, p. 327), the positive recognition 'is gained through talking better about (and to) Others, through better writings, and through better representational practices', and according to Galeotti (2009) with public 
argument. Recognition improves when the aid is universal and is basically given to all the disadvantaged (Fraser, 2003).

In contrast, highlighting and exposing the individual to demonstrate the necessity of certain material goods is a powerful tool for the majority or certain members within the group, in order to achieve power and the consolidation of the reification of individual or group. Fraser (2003) therefore recommends determining who benefits from the participation and proposes to carry out a double reflection on the benefits of cooperation within and between the groups. One effective regulatory tool against subordination and to determine the types of benefits of participation could be the instrument 'Response to Intervention' (RTI), described by Artiles et al. (2010, p. 251). RTI includes the analyses of social area and institutional pressure that have not been made until now and were not taken into account. RTI analyses the dominational patterns of the environment, the role of capability assessment, the role of the cultural and linguistic background of the pupil, and the role of the mediator power (ibid., p. 255). Kavkler, Košak Babuder and Magajna (2015, p. 46) have also expressed the need for the evaluation of the implementation of help in the school, after determining that the effectiveness of either implementing adaptations in the teaching process or providing additional assistance is never the subject of evaluation, unlike the performance of children with severe specific learning difficulties.

Compared with the programme of APA, in which the adjustments were awarded an affirmative character, adjustments in the programme LES and SP are structural in nature and given at the baseline (Rules on norms, 2007, 2008, 2014; Adapted educational programme..., 2003, 2013; Special programme..., 2014), therefore, bear the positive characteristics of transformative remedies. Differences between pupils in the same room (in the classroom) are reduced to a minimum, but only within programmes. The favourable ratio for pupils outside the classroom no longer applies. Nevertheless, at some point, the APA, LES an SP programmes can stigmatise the pupils, because they have to demonstrate significant need beforehand in order to receive those programmes. Therefore, the remedy for broadening the circle of inclusion to the widest possible space, both inside and outside the school (Honneth, 2003a; Kogovšek et al., 2009, West-Burnham, 2011) would contribute to a greater impact on pupil achievement, to a broader recognition and at the same time to increased possibility of the revaluation of cultural values.

\section{Conclusion}

By analysing the three areas of the concept of recognition, we found that the Slovenian system of allocating help to children with special needs and 
placement in programmes is based on differentiation and the demonstrating of in/capability (Kroflič, 2010; Lesar, 2008), which complicates the positive recognition of children with SEN. We note that the patterns of cultural values of noncompliance, inferiority and in-/capability are affecting the cooperation of children with SEN and their acceptance among peers. Research shows that children with SEN are silent pupils, are reluctant to be verbally exposed, have difficulties sharing their thoughts; this is especially so for pupils with speech and language difficulties (Čačinovič Vogrinčič, 2013; Higgins et al., 2009). Pupils do not make decisions about themselves in the classroom, and also not outside the classroom (Higgins et al., 2009). The possibility of children with SEN to make decisions would therefore mostly exist on paper, rather than be implemented in practice (also Kodele and Lesar, 2015). Common are the hidden effects of cultural patterns of inferiority and inability, which are related to the participation of children with SEN, in which we do not perceive the need of such children to demonstrate the achievements or the need to be involved in all sorts of extended school activities, which makes them invisible. The stereotypical descriptions of children with SEN do not contribute to the acceptance and understanding of their complexity as an individual (Keddie, 2012; Ozbič \& Jerković, 2007). Inadequate patterns of cultural values are reflected in lower or inferior knowledge (e.g. the name of the programme 'lower educational standard', also 'marginalised knowledge', Keddie, 2009, p. 272) and in the low expectations of teachers. According to Higgins et al. (2009, p. 478), some teachers believe that children with SEN need only basic knowledge; therefore, there is a belief that their teachers also need only basic knowledge and that anyone could teach children with SEN (Higgins et al., 2009, p. 478). Traditional teaching methods do not encourage the formation of social relationships, maintain passivity and subordination and do not create transformative conditions of recognition in places where they should be mostly present, particularly in the classroom (Artiles, Harris-Murri \& Rostenberg, 2006; Bingham, 2006; Koren et al., 2011; Lingard, 2007).

Using the concept of recognition, we determined three dangers of inclusion: displacement, reification, and a narrow context of participation. Participation is possible mostly within individual programmes. Displacement was seen in disregarding the connection between economic conditions and all kinds of participation of the pupils. In the area of assessment of children with SEN, different measurements of academic achievements may appear on the one hand and grades without credits on the other. The reification or management of children with SEN is reflected in paternalisation, biodeterminism, stereotypical notions of children with SEN and in keeping children with SEN in unsuitable programmes due to the benefits provided for guardians or educators. The 
avoidance of identity of children with SEN in the LES and SP programmes and in the type of school also occurs.

Disadvantages, which are the result of economic arrangements, are the insistence on the traditional teaching (which requires the least resources), difficult accessibility of adjustments (accessible mostly only with decision act provided by the commission for the placement of children with special needs), and the fact that we do not have the operationalisation of the transition from the LES programme to the mainstream primary school programme of an equal educational standard.

Separate legislation and regulations are governing the structural differences only within individual/separate programmes (e.g. significantly lower number of pupils and lower standards in programmes of LES and SP). The allocation of material rights is subject to the verification of capability; however, pupils' specific strengths could be taken into account.

With the help of the theoretical definitions, we formed the premise: 'I am a child with special needs, but I am visible, I have a voice, I am heard, I am successful, I have friends, I am observed, I have achievements, I may participate in the classroom, in extracurricular activities and beyond.' To achieve this goal, it is necessary to revert to remedies of a transformative character, which are placed at the baseline and are for example: organisation of joint activities, the use of active and collaborative ways of working, rewarding according to actual achievements, to possibility of additional education of the environment of a child with special needs, to provide visibility, voice and agency to each child, and the creation of transformative conditions in the classroom, at school and outside of school. For the realisation of all kinds of participation of pupils with special needs and to raise their achievements in schools, we need redistribution (additional resources, change of methods of work), recognition (change of oneself, attitudes and values) and a better representation (participation in the widest possible activities, actual decision-making, children are heard). In particular, balancing all three areas of recognition, taking into account the effects of patterns of cultural values, is recommended.

The three-dimensional model of social rights is particularly topical when the distribution problems are at the forefront of society. All the elements of social justice must be considered even more, as it more easily comes to the deepening of subordination also in the cultural field, due to distribution and political problems.

\section{Acknowledgments}

Sincere thanks to Prof. Martina Ozbič, $\mathrm{PhD}$, for her extensive and invaluable expert guidance and indispensable encouragements. 


\section{References}

Anastasiou, D., \& Kauffman, J. M. (2011). A social constructionist approach to disability: Implications for special education. Exceptional Children, 77(3), 367-384.

Anderson, E. (2008). Affirmative Action and Fraser's Redistribution-Recognition Dilemma. In K.

Olson (Ed.), Adding insult to injury: Nancy Fraser debates her critics (pp. 164-175). London: Verso.

Armstrong, D., Armstrong, A., \& Spandagou I. (2011). Inclusion: by choice or by chance?.

International Journal of Inclusive Education, 15(1), 29-39. doi:10.1080/13603116.2010.496192

Artiles, A. J., Bal, A., \& Thorius, K. (2010). Back to the Future: A Critique of Response to

Intervention's Social Justice Views. Theory Into Practice, 49(4), 250-257.

Artiles, A. J., Harris-Murri, N., \& Rostenberg, D. (2006). Inclusion as Social Justice: Critical Notes on

Discourses, Assumptions, and the Road Ahead. Theory Into Practice, 45(3), 260-268.

Artiles, A. J., Kozleski, E. B., Dorn, S., \& Christensen, C. (2006). Learning in Inclusive Education

Research: Re-Mediating Theory and Methods With a Transformative Agenda. Review of Research in

Education, 3o(Special edition), 65-108.

Batistič Zorec, M. (2010). Participacija otrok v slovenskih vrtcih z vidika stališč in izkušenj

vzgojiteljev. [Participation of children in Slovene kinderegartens from teachers' point of view and experiences ] In T. Devjak, M. Batistič Zorec, J. Vogrinc, D. Skubic, \& S. Berčnik (Eds.), Pedagoški koncept Reggio Emilia in kurilulum za vrtce: podobnosti v različnosti (pp. 77-85). Ljubljana: Faculty of Education, University of Ljubljana.

Bingham, C. (2006). Before Recognition and after: The Education Critique. Educational Theory, 56(3), 325-344.

Brenčič, I. (2011). Vedenjske značilnost učencev s posebnimi potrebami [Behavioral characteristics of children with special needs in primary school](Master's thesis). Ljubljana: Faculty of Education University of Ljubljana.

Convention on the Rights of the Child (1989). Retrieved 01.02.2012 from http://www.varuh-rs.si/ pravni-okvir-in-pristojnosti/mednarodni-pravni-akti-s-podrocja-clovekovih-pravic/organizacijazdruzenih-narodov/konvencija-o-otrokovih-pravicah-ozn/.

Convention on the Rights of Persons with Disabilities (2006). Retrieved 17.11.2015 from http://www. mddsz.gov.si/fileadmin/mddsz.gov.si/pageuploads/dokumenti_pdf/konvencija_o_pravicah_ invalidov_an.pdf.

Čačinovič Vogrinčič, G. (2013). Spoštovanje otroštva. [Respecting childhood] In T. Kodele, \& N.

Mešl (Eds.), Otrokov glas v procesu učenja in pomoči. priročnik za vrtce, šole in starše [Child's voice in the learning process and help. Manual for kindergartens, schools and parents] (pp. 11-40). Ljubljana: National Education Institute.

Čagran, B., \& Schmidt, M. (2011). Attitudes of Slovene teachers towards the inclusion of pupils with different types of special needs in primary school. Educational Studies, 37(2), 171-195. doi:10.1080/030 55698.2010 .506319

Danermark, B., \& Coniavitis Gellerstedt L. (2004). Social justice: redistribution and recognition-a 
non-reductionist perspective on disability. Disability \& Society, 19(4), 339-353.

De Boer, A., Pijl, S., \& Minnaert, A. (2011). Regular primary schoolteachers' attitudes towards inclusive education: a review of the literature. International Journal of Inclusive Education, 15(3), 331353. doi:10.1080/13603110903030089

De Silva, N. L. (2013). Inclusive Pedagogy in Light of Social Justice. Special Educational Rights and Inclusive Classrooms: on whose terms? A Field Study in Stockholm Suburbs. European Journal of Education, 48(3), 419-435. doi:10.1111/ejed.12032

Estell, D. B., Jones, M. H., Pearl, R., van Acker, R., Farmer, T. W., \& Rodkin, P. C. (2008). Peer Groups, Popularity, and Social Preference Trajectories of Social Functioning Among Students With and Without Learning Disabilities. Journal of Learning Disabilities, 41(1), 5-14.

Fraser, N. (1997). From Redistribution to Recognition? Dilemmas of Justice in a "Postsocialist" Age. In N. Fraser (Ed.), Justice Interruptus: Critical Reflections on the 'Postsocialist' Condition (pp. 1-21).

New York: Routledge. Retrieved 07.04.2010 from http://ethicalpolitics.org/blackwood/fraser.htm. Fraser, N. (2000). Rethinking recognition. New Left Review (3), 107-120.

Fraser, N. (2003). Distorted Beyond All Recognition: A Rejoinder to Axel Honneth. In N. Fraser, \& A. Honnet (Eds.), Redistribution or Recognition? A Political-Philosophical Exchange (pp. 198-236). London, New York: Verso.

Fraser, N. (2003a). Social Justice in the Age of Identitiy Politics: Redistribution, Recognition, and Participation. In N. Fraser, \& A. Honnet, (Eds.), Redistribution or Recognition? A PoliticalPhilosophical Exchange (pp. 7-109). London, New York: Verso.

Galeotti, A. E. (2009). Toleranca: pluralistični predlog. [Tolerance: pluralistic proposal] Ljubljana: Krtina.

Higgins, N., MacArthur, J., \& Kelly, B. (2009). Including disabled children at school: is it really as simple as 'a, c, d'?. International Journal of Inclusive Education, 13(5), 471-487.

Hočevar, A. (2010). Poročilo z okrogle mize o Delovni verziji osnutka predloga zakona o usmerjanju otrok s posebnimi potrebami [A report on the Panel Discussion on the Working Draft proposal for the placement of Children with Special Needs act]. Sodobna pedagogika, 61(1), 296-298.

Honneth, A. (2003a). The Point of Recognition: A Rejoinder to the Rejoinder. In N. Fraser, \& A. Honnet (Eds.), Redistribution or Recognition? A Political-Philosophical Exchange (pp. 237-256).

London, New York: Verso.

Honneth, A. (2003b). Redistribution as Recognition: A Response to Nancy Fraser. In N. Fraser, \&

A. Honnet (Eds.), Redistribution or Recognition? A Political-Philosophical Exchange (pp. 110-197).

London, New York: Verso.

Juriševič, M. (2011). Socialna vključenost nadarjenih učencev. [Social inclusion of gifted pupils] In B.

Borota, M. Cotič, D. Hozjan, \& L. Zenja (Eds.), Social Cohesion in Education (pp. 289-304). Horlivka: Ministry for Education and Science of Ukraine, Horlivka State Pedagogical Institute for Foreign Languages.

Kavkler, M., Košak Babuder, M., \& Magajna, L. (2015). Inclusive Education for Children with Specific Learning Difficulties: Analysis of Opportunities and Barriers in Inclusive Education in Slovenia. 
CEPS Journal, 5(1), 31-52.

Keddie, A. (2012). Schooling and social justice the lenses of Nancy Fraser. Critical Studies in Education, 53(3), 263-279.

Kellner, R., Houghton, S., \& Douglas, G. (2003). Peer-Related Personal Experiences of Children with Attention-Deficit / Hyperactivity Disorder With and Without Comorbid Learning Disabilities. International Journal of Disability, Development \& Education, 50(2), 11-136.

Kodele, T., \& Lesar, I. (2015). Ali formalni in strokovni dokumenti s področja šolstva spodbujajo participacijo učencev. [Do formal and professional documents in the field of education promote pupil participation?] Sodobna pedagogika, 66(3), 36-51.

Kogovšek, D., Ozbič, M., \& Košir, S. (2009). Inkluzivna praksa gluhih/naglušnih oseb v vzgojnoizobraževalnem sistemu Republike Slovenije. [Inclusive practice of deaf and hard of hearng children in Slovenian inclusive practice of deaf and hard of hearing children in Slovenia] Sodobna pedagogika, $60(1), 392-409$.

Končar, M., \& Lakič, M. (2004). Vzroki stresa pri učencih z lažjimi motnjami v duševnem razvoju. [Causes of stress in students with a mild disorder in mental development] Defectologica Slovenica Specialna in rehabilitacijska pedagogika, 12(1), 7-19.

Koren, A., MacBeath, J. E. C., \& Lepičnik-Vodopivec, J. (2011). Učenje učenja: delavnica 1. Učno gradivo. [Learnig to learn: Workshop 1. Learning material] Kranj: Šola za ravnatelje.

Koster, M., Nakken, H., Pijl, S., \& van Houten, E. (2009). Being part of the peer group: a literature study focusing on the social dimension of inclusion in education. International Journal of Inclusive Education, 13(2), 117-140. doi:10.1080/13603110701284680

Košir, S. (2008). Učenci s posebnimi potrebami v zunanjem preverjanju znanja. [Students with special needs in the external assessment of knowledge.] Defectologica Slovenica - Specialna in rehabilitacijska pedagogika, 16(3), 61-69.

Kovšca, A. (2014). Svetovalna storitev v Zakonu o usmerjanju otrok s posebnimi potrebami ter razlogi za njeno uvedbo. [Advisory services in the Placement of Children with special needs Act and the reason for its introduction] Šolsko svetovalno delo. Revija za svetovalne delavce v vrtcih, šolah in domovih, 13(1/2), 13-17.

Krek, J., \& Metljak M. (Eds.) (2011). Bela knjiga o vzgoji in izobraževanju v Republiki Sloveniji 2011 [The White paper on education in Slovenia.]. Ljubljana: Educational Research Institute. Kroflič, R. (2010a). Pripoznanje drugega kot drugačnega - element pravične obravnave marginaliziranih oseb in otrokovih pravic. [Recognition of Other as different: element of fair treatment of marginalized people and rights of the child.] In N. Ličen (Ed.), Kulture v dialogu (pp. 7-12). Ljubljana: Znanstvena založba Filozofske fakultete.

Kroflič, R. (2010b). Etična in politična dimenzija projekta Reggio Emillia. [Ethical and political dimension of the project Reggio Emilia.] In T. Devjak, M. Batistič Zorec, J. Vogrinc, D. Skubic, \& S. Berčnik (Eds.), Pedagoški koncept Reggio Emilia in kurikulum za vrtce: podobnosti v različnosti [Educational concept of Reggio Emilia and kindergarten curriculum: similarity in diversity] (pp. 11-66). Ljubljana: Faculty of Education, University of Ljubljana. 
Lesar, I. (2008). Analiza diskurzov in paradigem pri uresničevanju integracijskih in inkluzivnih teženj v šolskih sistemih. [The analysis of discourses and paradigms in the realisation of integration and inclusion tendencies in school systems.] Sodobna pedagogika, 59(3), 90-109.

Lindsay, G. (2007). Educational psychology and the effectiveness of inclusive education/ mainstreaming. British Journal of Educational Psychology, 77(1), 1-24.

Lingard, B. (2007). Pedagogies of indifference. International Journal of Inclusive Education, 11(3), 245-266.

McOuat R. C. (2011). Inclusion: Classroom Teachers' Perspectives and Experiences in a Bourdieusian Framework (Doctoral thesis). Chapel Hill: University of North Carolina.

Meadan, H., \& Monda-Amaya, L. (2008). Collaboration to Promote Social Competence for Students With Mild Disabilities in the General Classroom: A Structure for Providing Social Support.

Intervention in School \& Clinic, 43(3), 158-167.

Novljan, E. (2005). Dobra je odgovorna inkluzija. [Good is responsible inclusion.] Defectologica Slovenica - Specialna in rehabilitacijska pedagogika, vol. 13(3), 55-70.

Nacionalno preverjanje znanja. Letno poročilo o izvedbi v šolskem letu 2013/14 (2014). [National assessment of knowledge. Annuar report on implementation in school year 2013/14]. Ljubljana: Republiški izpitni center (RIC). Retrieved 6.10.2015 from http://www.ric.si/mma/Letno\%20 porocilo\%2oNPZ\%202014\%2odokoncno\%202/2014121113504097/.

Olli, J., Vehkakoski, T., \& Salanterä S. (2012). Facilitating and hindering factors in the realization of disabled children's agency in institutional contexts: literature review. Disability \& Society, $27(6)$, 793-807.

Olson, K. (2008). Participatory parity and democratic justice. In K. Olson (Ed.), Adding insult to injury: Nancy Fraser debates her critics (pp. 246-272). London: Verso.

Opara, B., Barle Lakota, A., Globačnik, B., Kobal Grum, D., Košir, Macedoni Lukšič, M., et al. (2010). Analiza vzgoje in izobraževanja otrok s posebnimi potrebami v Sloveniji. [Analysis of education of children with special needs in Slovenia.] Ljubljana: JRZ Educational Research Institute. Retrieved 11.04.2012 from http://www.google.si/url? $s a=t \& r c t=j \& q=\& e s r c=s \& s o u r c e=w e b \& c d=1 \& v e d=o C C$ gQFjAA\&url=http\%3A\%2F\%2Fwww.mizs.gov.si\%2Ffileadmin\%2Fmizs.gov.si\%2Fpageuploads\%2 Fpodrocje\%2Fposebne_potrebe\%2FGradivo_Analiza_vzgoje_in_izobrazevanja_OPP_v_Sloveniji. doc\&ei=SEP9UajwNs3AtAayhoHICA\&usg=AFQjCNHTo47MJZp6hqGwYC7GU_bB4f-_ Dg\&bvm=bv. 50165853 ,d.Yms.

O’Rourke, J., \& Houghton, S. (2006). Students with mild disabilities in regular classrooms: The development and utility of the Student Perceptions of Classroom Support scale. Journal of Intellectual \& Developmental Disability, 31(4), 232-242.

Ozbič, M., \& Žolgar Jerković, I. (2007). Nekritična prepričanja in napačne predstave o osebah z motnjo sluha bodočih učiteljic. [Mistanken beliefs and misconceptions of future teachers about hard-of-hearing people.] In T. Devjak, \& P. Zgaga (Eds.), Prispevki k posodobitvi pedagoških študijskih programov II [Contributions to Modernization of Educational Studies Programmes] (pp. 246-268). Ljubljana: Faculty of Education, University of Ljubljana. 
Posebni program vzgoje in izobraževanja (2014) [Special programme.] Uradni list RS No. 15/2014. Retrieved 06.10.2015 from http://www.mizs.gov.si/fileadmin/mizs.gov.si/pageuploads/podrocje/ posebne_potrebe/programi/posebni_program/Posebni_program_vzgoje_in_izob.pdf.

Prah, A. (2011). Socialne spretnosti učencev s primanjkljaji na posameznih področjih učenja v osnovni šoli (Magistrska naloga). [Social skills of pupils with learning difficulties in primary school] (Master's thesis). Ljubljana: Faculty of Education, University of Ljubljana.

Pravilnik o normativih in standardih za izvajanje vzgojno izobraževalnih programov za otrokes posebnimi potrebami $(2007,2008,2014)$ [Rules on norms and standards for the implementation of educational programmes for children with special needs]. Uradni list RS No. 59/2007, Uradni list RS No. 70/2008, Uradni list No. 56/2014.

Pravilnik o organizaciji in načinu dela komisij za usmerjanje otrok s posebnimi potrebami (2013) [Rules on the organization and working methods of commissions for the placement of children with special needs.] Uradni list RS No. 88/2013.

Pretnar, M. (2012). Medkulturna analiza stališč učiteljev do inkluzije otrok s posebnimi potrebami.

(Doktorska disertacija). [Intercultural analysis of standpoints of teachers towards inclusion of children with special needs] (Doctoral thesis). Ljubljana: Faculty of Education, University of Ljubljana.

Prilagojeni izobraževalni program devetletne osnovne šole z nižjim izobrazbenim standardom (2003, 2013) [Adapted educational nine-year primary school programme with lower educational standards] (Uradni list RS No. 100/2003, Uradni list RS No. 17/2013). Retrieved 06.10.2015 from http://www. mizs.gov.si/fileadmin/mizs.gov.si/pageuploads/podrocje/posebne_potrebe/programi/PP_z_NIS.pdf. Rinaldi, C. (2006). In Dialogue with Reggio Emilia. Listening, researching and learning. London, New Work: Routledge.

Robeyns, I. (2003). Is Nancy Fraser's Critique of Theories of Distributive Justice Justified?

Constellations: An International Journal Of Critical \& Democratic Theory, 10(4), 538-553.

Rovšek, M. (2009). Stanje na področju vključevanja otrok z motnjami v duševnem razvoju v šolski sistem. Neustreznost usmerjanja in nekaj predlogov za ukrepanje. [Current situation regarding the enrolment of children with mental disabilities into the education system. The inadequacy of the sen refferral process and some suggestions for future action.] Sodobna pedagogika 6o(1), 350-360. Rovšek, M. (2013). Značilnosti usmerjanja otrok in mladostnikov z motnjami v duševnem razvoju. (Doktorska disertacija). [Characteristics ot the referral process of the children and adolescents with intellectual disabilities] (Doctoral thesis). Ljubljana: Faculty of Education, University of Ljubljana. Rutar, S. (2011a). Razred in skupina otrok kot učeča se skupnost. [Classroom and group of children as a learning communitiy.] In B. Borota, M. Cotič, D. Hozjan, \& L. Zenja (Eds.), Social Cohesion in Education (pp. 171-186). Horlivka: Ministry for Education and Science of Ukraine, Horlivka State Pedagogical Institute for Foreign Languages.

Rutar, S. (2011b). Oblikovanje skupnosti v vrtcih in šolah. [Creation of communities in kindergardens and schools.] In B. Borota, \& D. Hozjan (Eds.), Strokovne podlage za oblikovanje socialne kohezivnost $v$ vzgoji in izobraževanju. II. del izobraževanja [Professional basis for the creation of social cohesion 
in education. II part of education] (pp. 51-58). Koper: Faculty of Education, University of Primorska. Schmidt, M., \& Čagran, B. (2005). Razredna klima v inkluzivnem razredu. [Atmosphere in the class in inclusive classroom.] Sodobna pedagogika, 56(4), 252-267.

Smith, A. B. (2007). Children and Young People's Participation Rights in Education. International Journal Of Children's Rights, 15(1), 147-164. doi:10.1163/092755607X181739

Solveig Reindal, M. (2010). What is the purpose? Reflection on inclusion and special education from a capabilty perspective. European Journal of Special Needs Education, 25(1), 1-11.

Šoln Vrbinc, P., Jakič Brezočnik, J., \& Arnuš Tabakovič, J. (2014). Novosti zakona o usmerjanju otrok s posebnimi potrebami (ZUOPP-1) [Novelties of the Placement of Children with Special Needs Act (ZUOPP-1)]. Šolsko svetovalno delo. Revija za svetovalne delavce v vrtcih, šolah in domovih, 13(1/2), 4-12.

Turnšek, N. (2008) Subjektivne teorije o otroštvu in vzgoji. [Subjecitve theories about childhod and education]. Ljubljana: Faculty of Education, University of Ljubljana.

Webster, A. A., \& Carter, M. (2013). A descriptive examination of the types of relationships formed between children with developmental disability and their closest peers in inclusive school settings. Journal Of Intellectual \& Developmental Disability, 38(1), 1-11. doi:10.3109/13668250.2012.743650. West-Burnham, J. (2011). “Kje so meje? Izobraževanje, šola in skupnost.” [Where Are the Boundaries? Education, School and Community.] Vodenje v vzgoji in izobraževanju 9(2), 3-15.

Winkler, M. (2011). O identiteti in inkluziji. [On identity and inclusion.] Sodobna pedagogika, 62(3), 52-68.

Zakon o usmerjanju otrok s posebnimi potrebami /ZUOPP-1/ (2011, 2012). [Placement of Chidren with Special Needs Act]. Uradni list RS No. 58/2011, Uradni list RS No. 90/2012.

Zavod republike Slovenije za šolstvo (ZRSŠ) [National Education Institute Slovenia] (NEIS). (2015). Spodbudno učno okolje za zagotavljanje enakih možnosti za v vzgoji in izobraževanju. [Stimulating learning environment for ensuring equal oportunities in education.] Retrieved 17.12.2015 from http:// www.zrss.si/projektiess/default.asp?pr=14.

\section{Biographical note}

MARJETA Šmid (MA in Science) is professor of defectology for people with physical and mental disabilities. She monitors and investigates lessons in the three programmes for the children with special needs in elementary school, publishes contributions and participates in the preparation of these programmes. She implemented the learning workshops, study groups for teachers, the innovation projects and she is mentor newly appointed head teachers. 